\title{
SALINITY AND TEMPERATURE VARIATIONS \\ IN THE SURFACE WATERS OF THE ARABIAN \\ SEA OFF THE BOMBAY AND SAURASHTRA COASTS
}

\author{
By R. Jayaraman AND S. S. Gogate \\ (Offshore Fisheries Research Unit of the Central Marine Fisheries Research Station, Bombay)
}

Received January 15, 1957

(Communicated by Dr. N. K. Panikkar)

CONTENTS

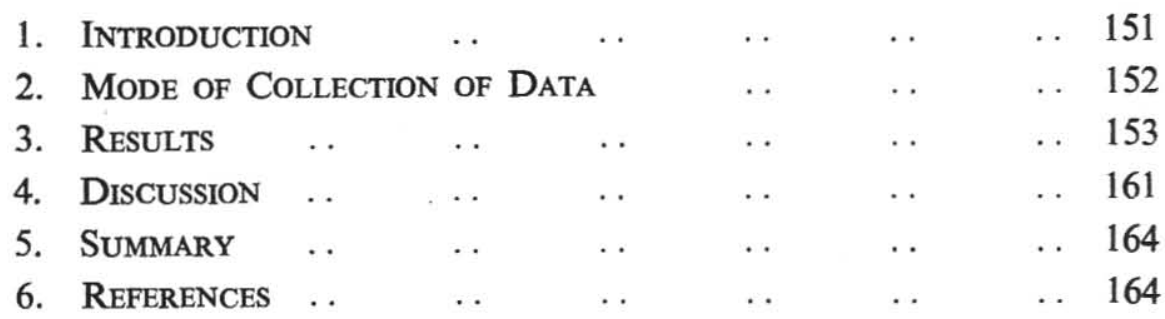

1. INTRODUCTION

THE waters of the Arabian Sea extending from the West-Coast of India down to 100 fathoms and lying between $18^{\circ}$ and $24^{\circ} \mathrm{N}$. latitude are of great importance from the point of view of the fishing industry, as they support some of the richest trawling grounds off the Indian Coast. The exploitation of these grounds in recent years has yielded much valuable information on the nature and extent of the fisheries of these grounds, but unfortunately, we have no information on the hydrological and other environmental conditions. Though there have been a number of oceanographic expeditions in the equatorial areas of the Indian Ocean, very few stations have been worked in this region. The "John Murray" Expedition (1933-34) has carried out extensive observations-both biological and hydrographical-mainly along the Southern Coast of Arabia (Sewell, 1955). The study of the conditions of the waters of the Arabian Sea nearer the Indian Coast on the other hand has been much neglected in the past. What little information we have of this region is mostly derived from the observations made on the survey ships of the British Admiralty. The only detailed publication on the physico-chemical conditions of the waters of the Arabian Sea near Bombay was that of Bal et al. (1946), but the data are very much restricted in scope,. their observations having been confined to the Bombay Harbour. 
The present investigations were started during 1953-54 as part of a regular programme of offshore fishery investigations. In the early period, however, the observations were made mainly on the trawlers working from Bombay, and as the collection of water samples and other oceanographical data had to be adjusted to the fishing routine, it was not possible to make more than a few isolated observations. This is because the fishing operations were very much restricted to a few areas and also to a few months of the year. These preliminary observations have, however, given us some idea of the main hydrological trends on these grounds.

With the initiation of the oceanography scheme at the Central Marine Fisheries Research Station and the organisation of systematic collection of wate samples and other oceanographical data, more opportunities were afforded to combine the work on the fishing vessels with the collection of data on other coastal vessels, including those belonging to the Indian Navy. The present paper is an attempt to summarise the observations made so far on the surface temperature and salinity distributions in the Bombay and Saurashtra waters and to work out the main trends in the hydrological conditions in these waters.

\section{Mode of Collection of Data}

Ships belonging to different organisations and plying from Bombay were provided with water sample bottles, thermometers for determining surface sea-water temperatures and oceanographical log sheets (the forms having been standardised at the Central Marine Fisheries Research Station, Mandapam). Detailed written instructions were given to the masters of all the vessels for the collection of essential oceanographic data and water samples for analysis. Arrangements were made to take charge of the water samples, logs, etc., soon after each ship completed one voyage and touched port. By employing a large number of vessels for this work, gaps in the collection of data were avoided to a large extent, though not completely. The water samples were analysed for salinity soon after they reached the laboratory by the standard titration procedure using silver nitrate. The temperature and salinity for each station (Fig. 1) worked by the ships were tabulated and $\sigma_{t}$ values were calculated. The data were grouped together in a manner similar to that described by Veen (1953) and the averages for each degree latitude* worked out.

* The data for each latitude were compiled by taking the values for stations half a degree on either side and averaging them. For example, the data for $19^{\circ} \mathrm{N}$. represent the average of all stations between $18^{\circ} 31^{\prime}$ and $19^{\circ} 30^{\prime} \mathrm{N}$. latitudes, the data for $20^{\circ} \mathrm{N}$. represent the average of all stations between $19^{\circ}-31^{\prime}$ and $-20^{\circ}-30^{\prime}$ N. latitude-and so en. 


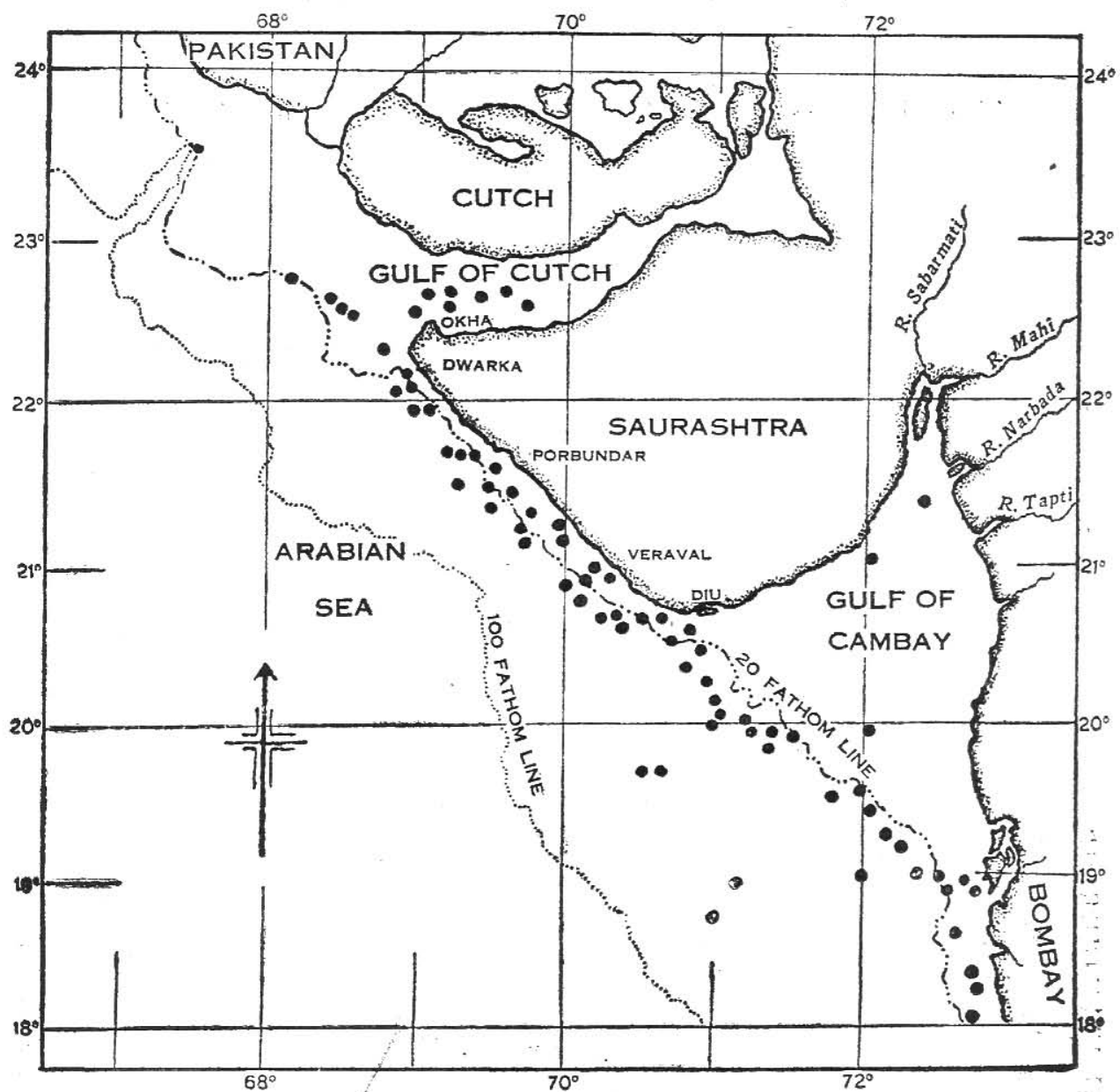

FIG. 1. Map showing the location of Sampling Stations.

3. Results

The following tables show the mean monthly values for salinity, temperature and $\sigma_{t}$ for each degree latitude between $18^{\circ}$ and $23^{\circ} \mathrm{N}$. latitude. The graphs (Figs. 2-6) give a clear picture of the seasonal trends in the different latitudes. For purposes of discussion, the conditions in each latitude are considered individually.

$18^{\circ} \mathrm{N}$. Latitude.-Data for this latitude are available only between October and March. It may be seen that the monthly range for surface salinities for the waters of this latitude is $33 \cdot 65 \%-36 \cdot 13 \%$. The rise is sudden from October to November, after which the salinity remains steady upto January. The maximum is reached in February. After February; the salinity falls down by $1 \cdot 28 \%$ to March. 
TABLE I

Showing the mean monthly values for temperature, chlorinity, salinity and density of the surface waters of the Arabian Sea in latitude $18^{\circ} \mathrm{N}$.

\begin{tabular}{|c|c|c|c|c|c|}
\hline \multicolumn{2}{|l|}{ Months } & \multirow{2}{*}{$\begin{array}{c}\text { Temperature } \\
{ }^{\circ} \mathrm{C} \text {. }\end{array}$} & \multirow{2}{*}{$\begin{array}{c}\text { Chlorinity } \\
\mathrm{Cl} \%\end{array}$} & \multirow{2}{*}{$\begin{array}{l}\text { Salinity } \\
\text { S\% }\end{array}$} & \multirow{2}{*}{$\begin{array}{c}\text { Density } \\
\sigma_{t}\end{array}$} \\
\hline $1955-$ & & & & & \\
\hline October & $\ldots$ & $26 \cdot 8$ & $18 \cdot 62$ & $33 \cdot 65$ & $21 \cdot 79$ \\
\hline November & . & $28 \cdot 3$ & $19 \cdot 77$ & $35 \cdot 71$ & 22.96 \\
\hline $\begin{array}{l}\text { December } \\
1956\end{array}$ & . & $25 \cdot 7$ & $19 \cdot 85$ & $35 \cdot 86$ & $23 \cdot 83$ \\
\hline January & $\ldots$ & $27 \cdot 0$ & $19 \cdot 78$ & $35 \cdot 74$ & $23 \cdot 32$ \\
\hline February & $\ldots$ & $25 \cdot 4$ & $20 \cdot 00$ & $36 \cdot 13$ & $24 \cdot 10$ \\
\hline March $\quad \ldots$ & . & $27 \cdot 9$ & $19 \cdot 29$ & $34 \cdot 85$ & $22 \cdot 32$ \\
\hline
\end{tabular}

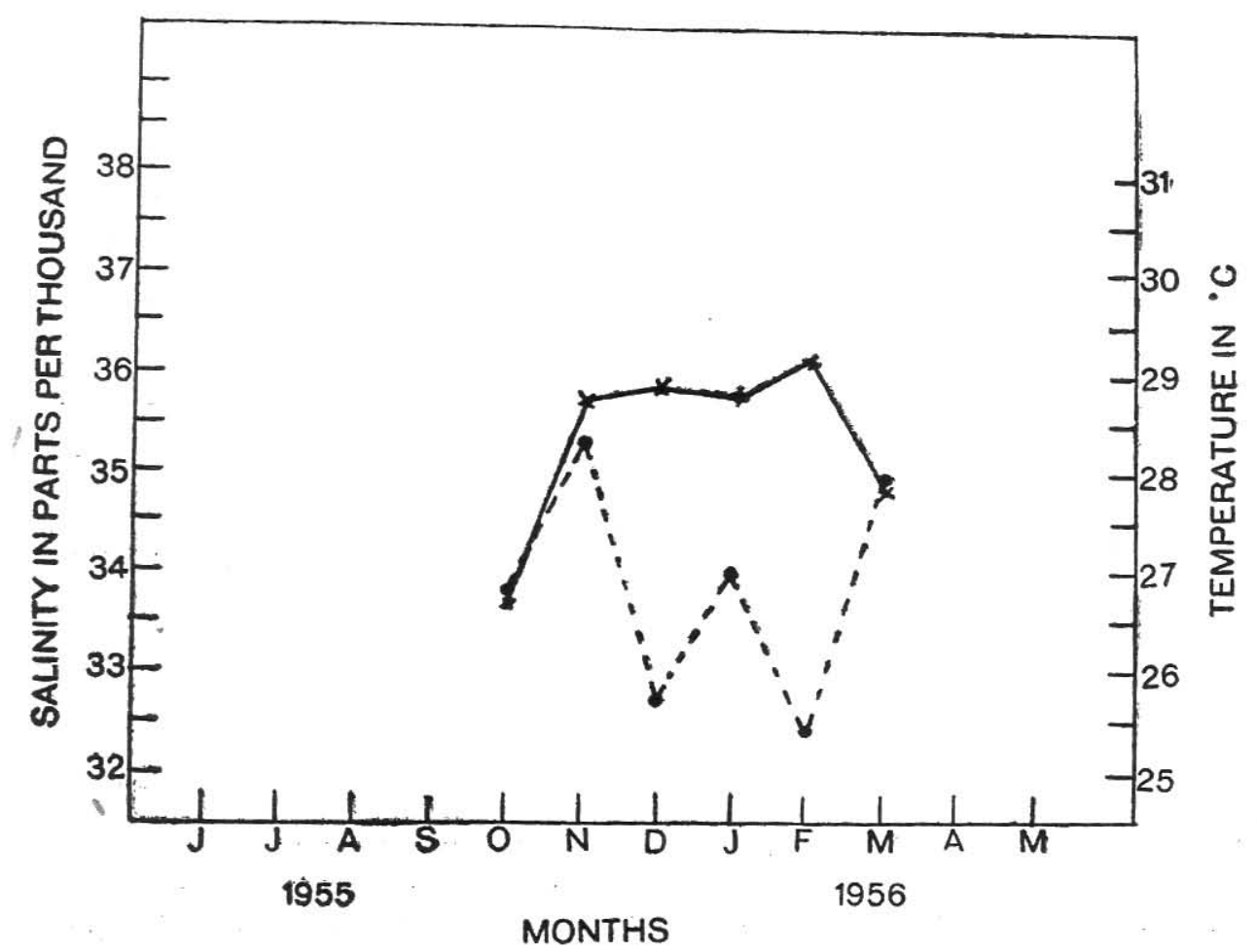

'FIg. 2. Surface Temperature and Salinity in Different Months in the Waters of the Arabian Sea in Latitude $18^{\circ} \mathrm{N} . \times-\ldots \times$ Salinity. 


\section{TABLE II}

Showing the mean monthly values for temperature, chlorinity, salinity and density of the surface waters of the Arabian Sea in latitude $19^{\circ} \mathrm{N}$.

\begin{tabular}{|c|c|c|c|c|c|}
\hline Mont & & $\begin{array}{c}\text { Temperature } \\
{ }^{\circ} \text {. }\end{array}$ & $\begin{array}{c}\text { Chlorinity } \\
\mathrm{Cl} \%\end{array}$ & $\underset{\mathrm{S} \%}{\text { Salinity }}$ & $\begin{array}{c}\text { Density } \\
\sigma_{t}\end{array}$ \\
\hline \multicolumn{6}{|l|}{$1955-$} \\
\hline June & & $28 \cdot 3$ & $19 \cdot 90$ & $35 \cdot 95$ & $23 \cdot 06$ \\
\hline July & .. & $28 \cdot 3$ & $19 \cdot 65$ & $35 \cdot 50$ & $22 \cdot 70$ \\
\hline August . & .. & \multicolumn{4}{|c|}{ No data available for this month } \\
\hline September & .. & $27 \cdot 0$ & $18 \cdot 57$ & $33 \cdot 55$ & $21 \cdot 69$ \\
\hline October. & .. & $28 \cdot 5$ & $19 \cdot 27$ & $34 \cdot 81$ & $22 \cdot 16$ \\
\hline November & .. & $28 \cdot 3$ & $19 \cdot 60$ & $35 \cdot 41$ & $22 \cdot 64$ \\
\hline December & .. & $27 \cdot 7$ & $20 \cdot 01$ & $36 \cdot 15$ & $23 \cdot 38$ \\
\hline \multicolumn{6}{|l|}{ 1956- } \\
\hline $\begin{array}{l}\text { Jamuary .. } \\
\text { February }\end{array}$ & . & $25 \cdot 9$ & $19 \cdot 85$ & $35 \cdot 87$ & $23 \cdot 77$ \\
\hline February . & .. & $25 \cdot 2$ & $19 \cdot 74$ & $35 \cdot 67$ & $23 \cdot 82$ \\
\hline
\end{tabular}

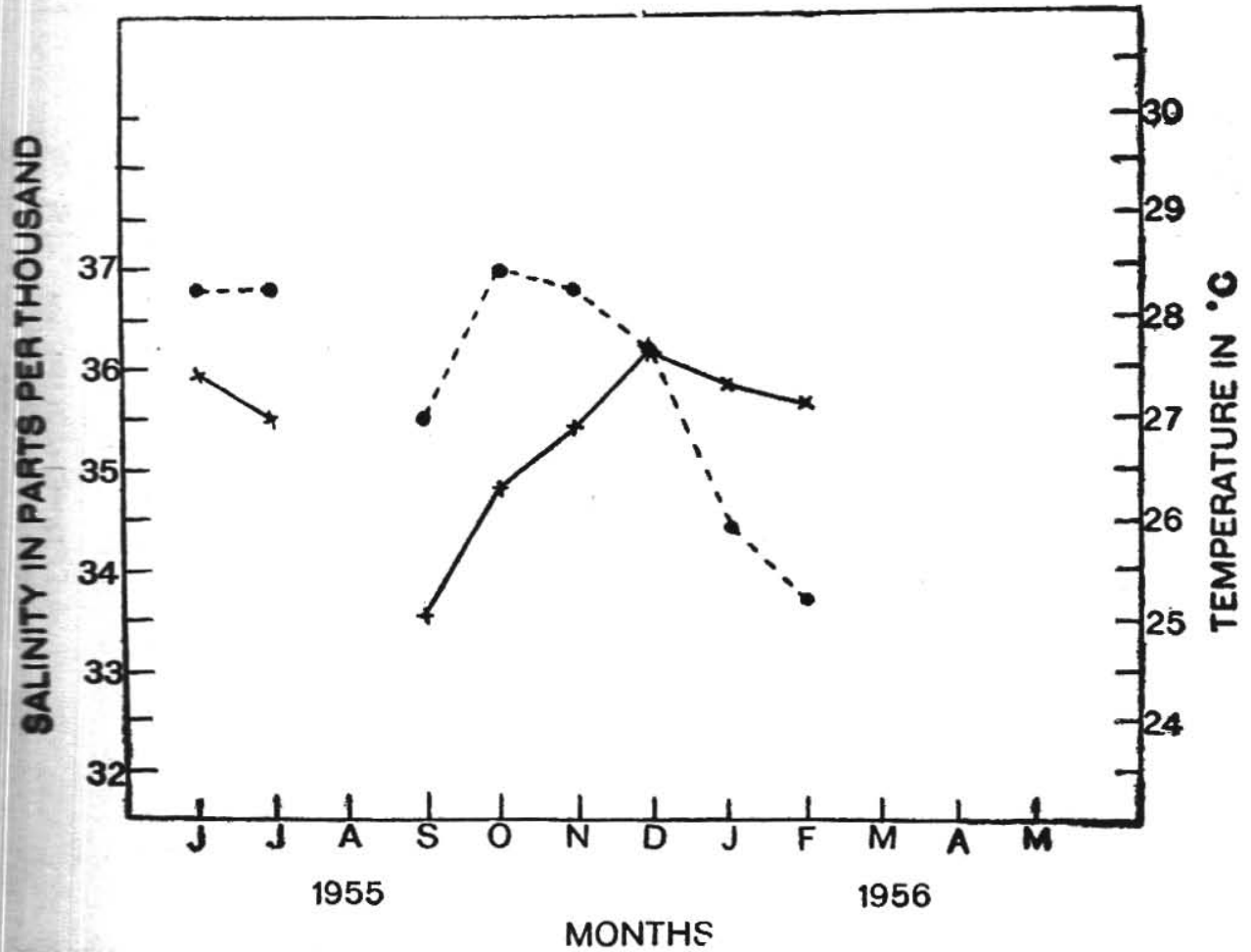

Fig. 3. Surface Temperature and Salinity in the Different Months in the Waters of the Arabian

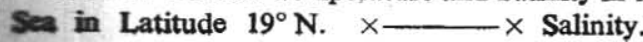




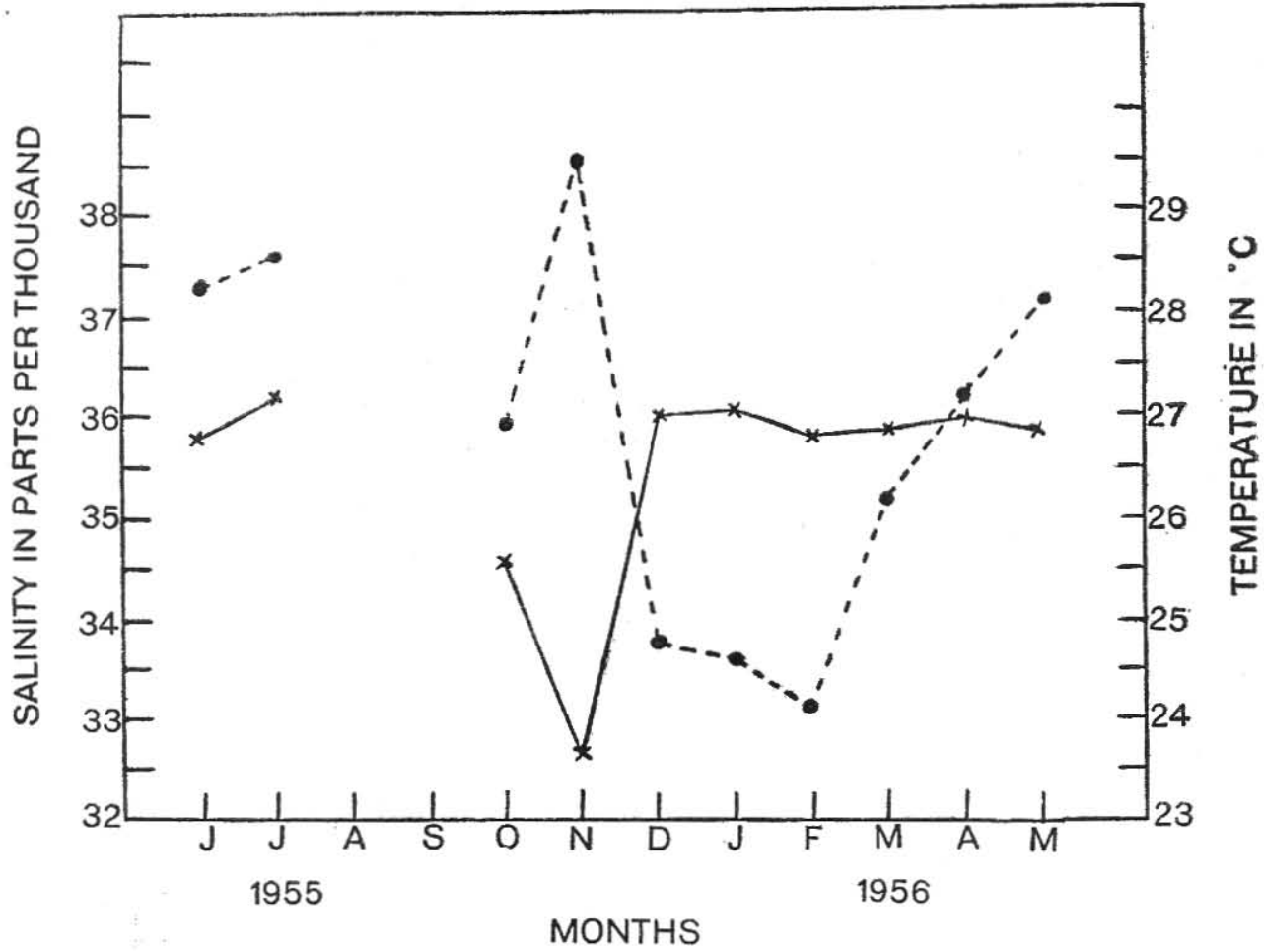

FIG. 4. Surface Temperature and Salinity in the Different Months in the Waters of the Arabian Sea in Latitude $20^{\circ}$ N. $\times \longrightarrow \times$ Salinity. Temperature.

\section{TABLE III}

Showing the mean monthly values for temperature, chlorinity, salinity and density of the surface waters of the Arabian Sea in latitude, $20^{\circ} \mathrm{N}$.

\begin{tabular}{|c|c|c|c|c|c|c|}
\hline \multicolumn{3}{|c|}{ Months } & $\begin{array}{c}\text { Temperature } \\
{ }^{\circ} \text {. }\end{array}$ & \multirow{2}{*}{$\begin{array}{c}\text { Chlorinity } \\
\mathrm{Cl} \%\end{array}$} & \multirow{2}{*}{$\begin{array}{l}\text { Salinity } \\
\text { S\% }\end{array}$} & \multirow{2}{*}{$\begin{array}{c}\text { Density } \\
\sigma_{t}\end{array}$} \\
\hline $1955-$ & & & & & & \\
\hline June & . & $\ldots$ & $28 \cdot 3$ & $19 \cdot 80$ & $35 \cdot 77$ & $22 \cdot 92$ \\
\hline July & . & . & $28 \cdot 6$ & $20 \cdot 04$ & $36 \cdot 20$ & $23 \cdot 11$ \\
\hline August & . & .. & \multicolumn{4}{|c|}{ Data not available } \\
\hline September & & . . & \multicolumn{4}{|c|}{ Data not available } \\
\hline October & . & . & $26 \cdot 9$ & $19 \cdot 14$ & $34 \cdot 58$ & $22 \cdot 49$ \\
\hline November & & $\ldots$ & $29 \cdot 5$ & $18 \cdot 07$ & $32 \cdot 65$ & $19 \cdot 28$ \\
\hline December & r & . & $24 \cdot 7$ & $19 \cdot 94$ & $36 \cdot 02$ & $24 \cdot 26$ \\
\hline \multicolumn{7}{|c|}{1956} \\
\hline January & . & . & $24 \cdot 6$ & $19 \cdot 95$ & $36 \cdot 05$ & $24 \cdot 31$ \\
\hline February & . & . & $24 \cdot 1$ & $19 \cdot 83$ & $35 \cdot 82$ & $24 \cdot 28$ \\
\hline March & . & . & $26 \cdot 2$ & $19 \cdot 85$ & $35 \cdot 87$ & $23 \cdot 67$ \\
\hline April & . & . & $27 \cdot 02$ & $19 \cdot 95$ & $36 \cdot 04$ & $23 \cdot 56$ \\
\hline May & $\ldots$ & $\ldots$ & $28 \cdot 3$ & $19 \cdot 78$ & $35 \cdot 73$ & $22 \cdot 91$ \\
\hline
\end{tabular}




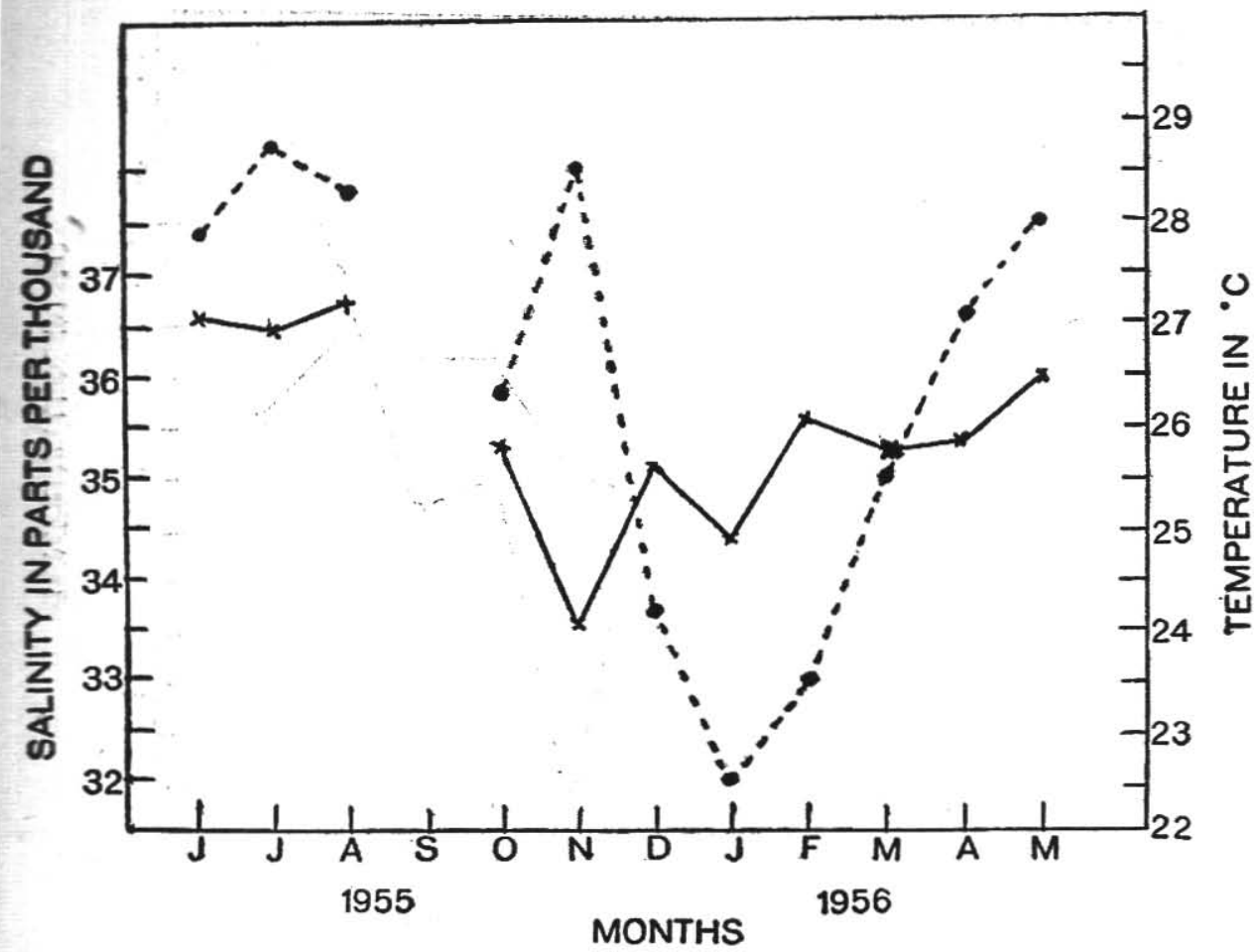

Fig. 5. Surface Temperature and Salinity in the Different Months in the Waters of the Arabian Sea in Latitude $21^{\circ} \mathrm{N}$. $\times \longrightarrow \times$ Salinity. Temperature.

\section{TABLE IV}

Showing the mean monthly values for temperature, chlorinity, salinity and density of the surface waters of the Arabian Sea in latitude $21^{\circ} \mathrm{N}$.

\begin{tabular}{|c|c|c|c|c|c|c|}
\hline \multicolumn{2}{|c|}{ Months } & \multicolumn{2}{|r|}{$\begin{array}{c}\text { Temperature } \\
{ }^{\circ} \mathrm{C} .\end{array}$} & \multirow{2}{*}{$\begin{array}{l}\text { Chlorinity } \\
\mathrm{Cl} \%\end{array}$} & \multirow{2}{*}{$\begin{array}{c}\text { Salinity } \\
\mathrm{S} \%\end{array}$} & \multirow{2}{*}{$\begin{array}{c}\text { Density } \\
\sigma_{t}\end{array}$} \\
\hline 1955 & & & & & & \\
\hline June & $\ldots$ & $\ldots$ & $27 \cdot 9$ & $20 \cdot 26$ & $36 \cdot 60$ & $23 \cdot 70$ \\
\hline July & . & . & $28 \cdot 8$ & $20 \cdot 18$ & $36 \cdot 45$ & $23 \cdot 24$ \\
\hline August & $\cdots$ & $\cdots$ & $28 \cdot 3$ & $20 \cdot 35$ & $36 \cdot 76$ & $23 \cdot 66$ \\
\hline Septembe & & $\ldots$ & \multicolumn{4}{|c|}{ Data not available } \\
\hline October & & . & $26 \cdot 3$ & $19 \cdot 54$ & $35 \cdot 30$ & $23 \cdot 19$ \\
\hline Novembe & & . & $28 \cdot 5$ & $18 \cdot 57$ & $33 \cdot 55$ & $21 \cdot 21$ \\
\hline December & & $\cdots$ & $24 \cdot 3$ & $19 \cdot 44$ & $35 \cdot 11$ & $23 \cdot 64$ \\
\hline $1956-$ & & & & & & \\
\hline January & $\ldots$ & & $22 \cdot 5$ & $19 \cdot 18$ & $34 \cdot 65$ & $23 \cdot 85$ \\
\hline February & $\cdots$ & $\cdots$ & $23 \cdot 5$ & $19 \cdot 70$ & $35 \cdot 60$ & $24 \cdot 28$ \\
\hline March & . & . & $25 \cdot 5$ & $19 \cdot 53$ & $35 \cdot 28$ & $23 \cdot 42$ \\
\hline April & . & . & $27 \cdot 03$ & $19 \cdot 57$ & $35 \cdot 35$ & $23 \cdot 01$ \\
\hline May & . & . & $28 \cdot 0$ & 19.93 & $36 \cdot 00$ & $23 \cdot 21$ \\
\hline
\end{tabular}




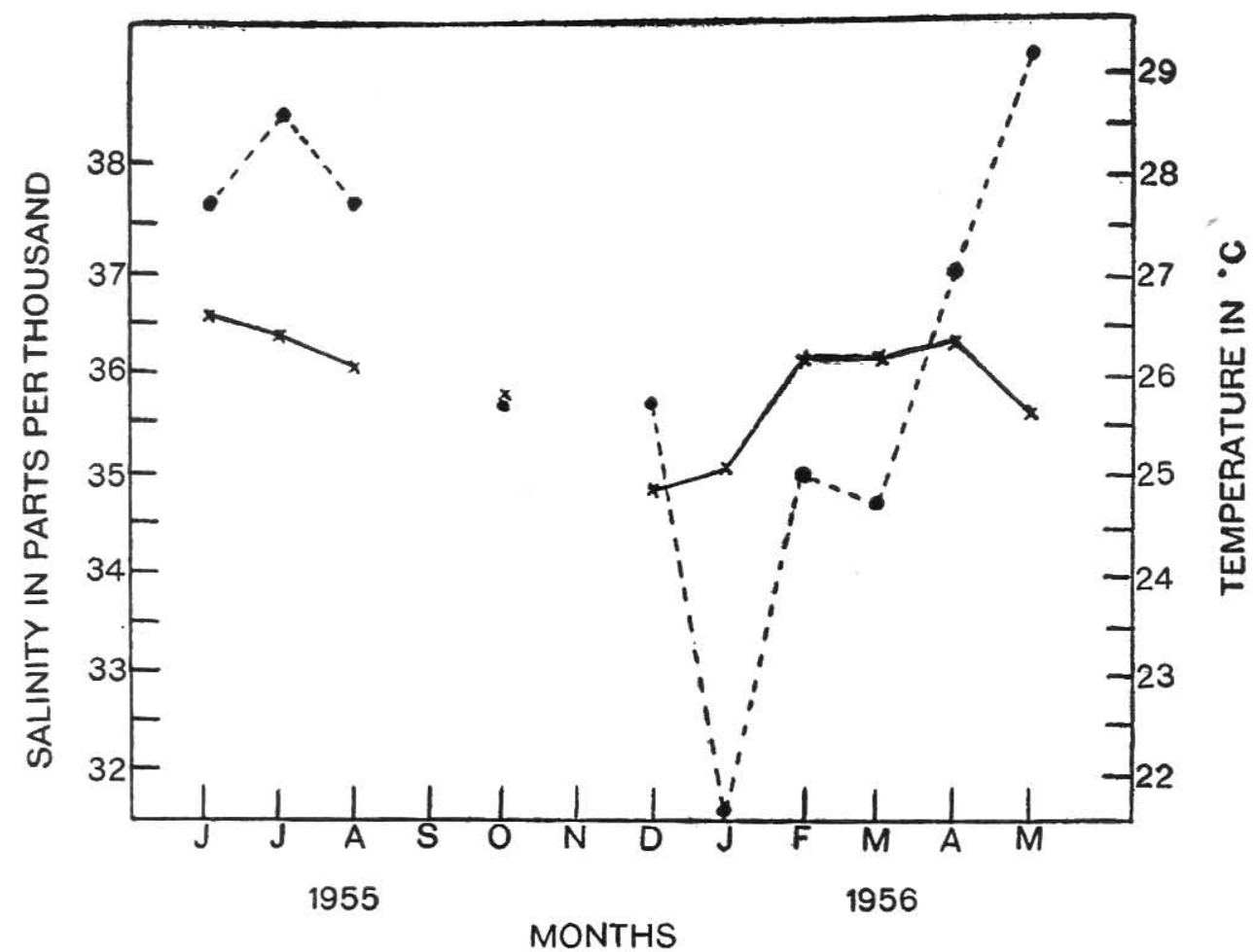

FIG. 6. Surface Temperature and Salinity in the Different Months in the Waters of the Sea in Latitude $22^{\circ} \mathrm{N}$. $\times \longrightarrow \times$ Salinity.

Temperature.

\section{TABLE V}

Showing the mean monthly values for temperature, chlorinity, salinity and density of the surface waters of the Arabian Sea in latitude $22^{\circ} \mathrm{N}$.

\begin{tabular}{|c|c|c|c|c|c|c|}
\hline \multicolumn{2}{|c|}{ Months } & \multicolumn{2}{|r|}{$\begin{array}{c}\text { Temperature } \\
{ }^{\circ} \mathrm{C} .\end{array}$} & \multirow{2}{*}{$\begin{array}{c}\text { Chlorinity } \\
\mathrm{Cl} \%\end{array}$} & \multirow{2}{*}{$\begin{array}{l}\text { Salinity } \\
\mathrm{S} \% \text { o }\end{array}$} & \multirow{2}{*}{$\begin{array}{c}\text { Density } \\
\sigma_{t}\end{array}$} \\
\hline $1955-$ & & & & & & \\
\hline June & . . & $\ldots$ & $27 \cdot 7$ & $20 \cdot 25$ & $36 \cdot 58$ & $23 \cdot 70$ \\
\hline July & $\begin{array}{l}\cdots \\
\ldots\end{array}$ & $\cdots$ & $28 \cdot 6$ & $20 \cdot 14$ & $36 \cdot 39$ & $23 \cdot 26$ \\
\hline August & $\ldots$ & . & $27 \cdot 7$ & $19 \cdot 96$ & $36 \cdot 06$ & $23 \cdot 35$ \\
\hline Septembe & & . & & Data $n$ & available & \\
\hline October & & $\cdots$ & $25 \cdot 7$ & $19 \cdot 80$ & $35 \cdot 77$ & $23 \cdot 76$ \\
\hline Novembe & & $\cdots$ & & Data not & ailable & \\
\hline December & & $\cdots$ & $25 \cdot 7$ & $19 \cdot 30$ & $34 \cdot 87$ & $23 \cdot 06$ \\
\hline 1956 & & & & & & \\
\hline January & $\ldots$ & $\ldots$ & $21 \cdot 6$ & $19 \cdot 43$ & $35 \cdot 10$ & $24 \cdot 42$ \\
\hline February & $\cdots$ & $\cdots$ & $25 \cdot 0$ & $20 \cdot 02$ & $36 \cdot 17$ & $24 \cdot 25$ \\
\hline March & $\ldots$ & . & $24 \cdot 7$ & $20 \cdot 01$ & $36 \cdot 15$ & $24 \cdot 30$ \\
\hline April & . & $\cdots$ & $27 \cdot 0$ & $20 \cdot 12$ & $36 \cdot 35$ & $23 \cdot 74$ \\
\hline May & . & .. & $29 \cdot 2$ & $19 \cdot 67$ & $35 \cdot 53$ & $22 \cdot 44$ \\
\hline
\end{tabular}


Salinity and Temperature Variations in Surface Waters of Arabian Sea 159

\section{TABLE VI}

Showing the mean monthly values for temperature, chlorinity, salinity and density of the surface waters of the Arabian Sea in latitude $23^{\circ} \mathrm{N}$.

\begin{tabular}{|c|c|c|c|c|c|c|}
\hline \multicolumn{2}{|c|}{ Months } & \multicolumn{2}{|r|}{$\begin{array}{c}\text { Temperature } \\
{ }^{\circ} \mathrm{C} \text {. }\end{array}$} & \multirow[t]{2}{*}{$\begin{array}{c}\text { Chlorinity } \\
\mathrm{Cl} \%\end{array}$} & \multirow[t]{2}{*}{$\begin{array}{l}\text { Salinity } \\
\mathrm{S} \%\end{array}$} & \multirow[t]{2}{*}{$\begin{array}{c}\text { Density } \\
\sigma_{t}\end{array}$} \\
\hline $1955-$ & & & & & & \\
\hline June & . . & . & $28 \cdot 8$ & $20 \cdot 59$ & $37 \cdot 19$ & $23 \cdot 84$ \\
\hline July & . & . & $28 \cdot 8$ & $20 \cdot 02$ & $36 \cdot 17$ & $23 \cdot 04$ \\
\hline August & . & . & \multicolumn{4}{|c|}{ Data not available } \\
\hline Septembe & & $\ldots$ & \multicolumn{4}{|c|}{ Data not available } \\
\hline October & . & . & \multicolumn{4}{|c|}{ Data not available } \\
\hline November & & . & \multicolumn{4}{|c|}{ Data not available } \\
\hline $\begin{array}{l}\text { December } \\
1956\end{array}$ & & $\cdots$ & $25 \cdot 5$ & $20 \cdot 20$ & $36 \cdot 50$ & $24 \cdot 33$ \\
\hline January & $\ldots$ & $\ldots$ & $21 \cdot 0$ & $20 \cdot 27$ & $36 \cdot 62$ & $25 \cdot 74$ \\
\hline February & . & . & \multicolumn{4}{|c|}{ Data not available } \\
\hline March & . & . & $25 \cdot 0$ & $20 \cdot 49$ & $37 \cdot 01$ & $24 \cdot 90$ \\
\hline April & $\cdots$ & & \multicolumn{4}{|c|}{ Data not available } \\
\hline May & $\cdots$ & $\cdots$ & $28 \cdot 5$ & $20 \cdot 13$ & $36 \cdot 36$ & $23 \cdot 27$ \\
\hline
\end{tabular}

In the case of surface temperature, there appears to be an alternation of high and low values. From $26.8^{\circ} \mathrm{C}$. in the month of October, there is an increase to $28 \cdot 3^{\circ} \mathrm{C}$. in November, followed by a sudden fall to $25 \cdot 7^{\circ} \mathrm{C}$. in December. Again there is a rise to $27^{\circ} \mathrm{C}$. in January, a fall to $25 \cdot 4^{\circ} \mathrm{C}$. in February, and then an increase to $28.0^{\circ} \mathrm{C}$. in March.

$19^{\circ} \mathrm{N}$. Latitude.-During the months of the South-West monsoon, June and July, the surface temperature has been steady at $28 \cdot 3^{\circ} \mathrm{C}$., while the salinity has varied from $35 \cdot 95 \%$ to $35 \cdot 50 \%$. In the following period, the temperature has risen from $27^{\circ} \mathrm{C}$. in September to $28 \cdot 5^{\circ} \mathrm{C}$. in October and then. remained almost steady upto the end of November. The salinity has also shown an increase, the highest value being in December. The temperature, on the other hand, has recorded a fall by about $0 \cdot 6^{\circ} \mathrm{C}$. in December. In the months of January and February, both the salinity and temperature have shown a fall, the drop in the case of the latter being more sharp. The conditions in the subsequent months are not known, as the data for these months are not available.

$20^{\circ} \mathrm{N}$. Latitude.-In this region, which includes the waters of the Gulf of Cambay, the conditions during the South-West monsoon are almost similar to those observed in $19^{\circ} \mathrm{N}$. Latitude. The trends are somewhat 
different in the two areas in the months following the South-West monsoon. While the temperature continues to be high, the salinity has shown a marked decrease in the months of October and November, more particularly so in the latter. The temperature in November is as high as $29 \cdot 5^{\circ} \mathrm{C}$., probably the highest for the season, barring, of course, the summer months, while the salinity is as low as $32.65 \%$. In December the trend is completely reversed. The temperature has come down to $24 \cdot 7^{\circ} \mathrm{C}$. and the salinity has shown a sharp rise to $36.02 \%$. This change is seen to be very sudden. The high salinity persists thereafter till the end of May. The temperature, on the other hand, shows a further reduction to $24.1^{\circ} \mathrm{C}$. in February and in March there is a sudden increase to $26 \cdot 2^{\circ} \mathrm{C}$.

$21^{\circ} \mathrm{N}$. Latitude.-The monthly trends are more or less the same as in the previous latitude. The salinity values during the South-West monsoon are somewhat higher. Between June and August, the salinity has varied from $36 \cdot 45 \%-36 \cdot 76 \%$. Lowest values for salinity are reached in November, the mean value being $33.55 \%$. The sharp rise in salinity and drop in temperature are seen in December as in the previous case. But there are a few differences which deserve mention. The rise in salinity in December is slightly of a smaller order of magnitude than in latitude $20^{\circ} \mathrm{N}$. Secondly, in the months following December, although a general tendency for higher values for salinity is seen, very often the hgih values are preceded and followed by slightly lower values. The increase in salinity thus proceeds in stages to the highest value of $36.00 \%$ in May. In the case of temperature, the initial lowering is similar to what has been seen in the latitude $20^{\circ} \mathrm{N}$. The first lowering is from $28.5^{\circ} \mathrm{C}$. in November to $24.3^{\circ} \mathrm{C}$. in December. The reduction in temperature continues and the lowest value is reached in January, the mean temperature in this month being $22.5^{\circ} \mathrm{C}$. A slight increase to $23.5^{\circ} \mathrm{C}$. is observed in February, but in March the rise is sharp, the value being $25.5^{\circ} \mathrm{C}$. It may, therefore, be seen that, barring the few differences mentioned above, the general pattern of salinity and temperature distribution is the same in the latitudes $20^{\circ}$ and $21^{\circ} \mathrm{N}$. The sudden changes noticed in these latitudes appear to be significant and will be discussed later.

$22^{\circ} \mathrm{N}$. Latitude.-The variations in salinity and temperature in this region show a somewhat different picture from what has been described before. The trend is a lowering of salinity from $36 \cdot 60 \%$ in June to about $35 \%$ in December and January followed by a rise to about $36.17 \%$ in February and the steady maintenance of this value upto the end of April. In May the salinity has come down to $35 \cdot 53 \%$. The temperature, on the other hand, shows a rather wide fluctuation. Between June and August, the mean values for temperature ranged between $27 \cdot 7^{\circ} \mathrm{C}$. and $28.6^{\circ} \mathrm{C}$. 
In October, the value has come down to $25 \cdot 7^{\circ} \mathrm{C}$. A decrease to $21 \cdot 6^{\circ} \mathrm{C}$. is seen in January, after which there is an increase to $25^{\circ} \mathrm{C}$. which is followed by a slight drop to $24 \cdot 7^{\circ} \mathrm{C}$. The highest value for temperature $29 \cdot 2^{\circ} \mathrm{C}$. is reached in the month of May.

$23^{\circ} \mathrm{N}$. Latitude.-Very high salinities are found in the waters of this latitude - the average monthly salinity range being $36 \cdot 17 \%-37 \cdot 19 \%$. The highest values have been observed in June and March of the following year. The temperatures are high in June and July and low from December onwards till next March. The value is again high in May- $28 \cdot 5^{\circ} \mathrm{C}$. Unfortunately, the data for this region are rather scrappy and hence a continuous picture of the conditions has not been obtained. The lowest surface temperature has been obtained in January, the value being $21^{\circ} \mathrm{C}$. The salinity remains practically unchanged, the mean annual range of variation being $1.02 \%$. The waters from inside the Gulf of Cutch seem to play a dominant role in affecting the hydrological conditions of these waters.

\section{Discussion}

The main factors controlling the distribution of surface temperature and surface salinity in Ocean waters have been discussed in great detail by Sverdrup et al. (1942). According to these authors, the surface salinity variations are determined by three processes:

(1) Decrease of salinity by precipitation;

(2) Increase of salinity by evaporation; and

(3) Change of salinity by processes of mixing.

These are probably the main factors affecting the distribution of surface salinity in the open oceans; whereas in coastal waters complications are introduced due to shifts in the coastal currents.

In the case of temperature, on the other hand, the controlling factors are a little more complicated. The annual variations in temperature are mainly due to the changes in the currents, vertical motion, seasonal heating and cooling and heat conduction.

In examining the present data with a view to explaining the observed variations in salinity and temperature, both in time and space, it would be necessary to have an idea of the prevalent current systems in these waters. A fairly detailed account of the currents in the Arabian Sea is given in the West Coast of India Pi'ot, published by the British Admiralty (1950) and also by Sewell (1955). It is seen that the main currents are those associated with the prevailing South-West and North-East monsoons, the speed and direction of these currents being regulated by the coastal confor- 
mation. Besides these wind-driven currents, there are tidal streams of fairly high velocity, originating in the Gulf of Cambay and Gulf of Cutch, which play an equally significant, if not more important, part in governing the hyrdrological conditions of these waters.

During the months of the South-West monsoon, the general flow of the surface water is from West to East over the greater part of the Arabian Sea (Sewell, 1955). Due to the effect of the winds, the waters nearer our coast assume the character of the offshore waters, because of the "banking up " of the waters near the coast, sinking of these waters and replacement by more of the surface drift from the open sea. This may partly explain the prevalence of high salinities in these waters during the months of the SouthWest monsoon, in spite of the fact that the heavy rains during the season tend to dilute the surface waters, thereby lowering the surface salinity. The expected dilution effects of the rains are offset by the incursion of more saline waters of the open sea. The temperature, as could be seen, is also high during these months and this, again, could be ascribed to the incursion of the warm offshore waters.

October and early November form the transition between the cessation of the South-West monsoon and the commencement of the North-East monsoon. The winds are practically absent during this transition period. In October, the surface waters get heated to a considerable extent, which may explain the prevalence of high surface temperatures in this month and in early November also. There should be a certain amount of evaporation during these months, but this probably is countered by the influx of fresh-water. This is particularly noticeable in the Gulf of Cambay and a little to the North of it upto $21^{\circ} \mathrm{N}$. latitude. The lowest salinities observed in the months of October and November are, therefore, to be attributed to dilution caused by the mixing of large volumes of fresh-water from the rivers like Narbada, Tapti, etc., which open out into the Gulf of Cambay (see Fig. 1). It is interesting to note that such marked lowering in salinity has not been noticed in the waters further North-around $22^{\circ} \mathrm{N}$. latitude. This is mainly due to the absence of any major rivers in the vicinity of this latitude.

From the latter half of November, there is a change in the conditions. The predominant winds are from the North and North-East. With the onset of these winds, the pattern of currents also changes. It is a well-known fact that owing to the combined action of the wind and the effect of rotation of the earth, the surface waters of the oceans in the northern hemisphere will be forced in a direction of about 45 degrees to the right of the wind direction. Thus it may be seen that during this season, the surface waters tend 
to be taken more and more away from our coast. During the same season, Sewell (1955) has reported that on the East African and Arabian Coasts, the surface water tends to be "banked up" near the coast. As a consequence of these water movements, nearer our coast a certain amount of upwelling from moderate depths will be taking place to replace the water driven seawards, the intensity as well as the extent of this upwelling being determined by the force and duration of the wind. It may be seen that the hydrological conditions of these waters, particularly around $20^{\circ}-21^{\circ} \mathrm{N}$. latitude and to a slightly less extent in $22^{\circ} \mathrm{N}$. latitude, undergo a sudden change immediately after November. The high surface temperature and low salinity of the October-November period give place to low temperature and high salinity almost within a few days. Such a condition persists from December to almost the end of February. It is quite possible that this type of change in the conditions is due to the upwelling of the coastal waters, which has resulted in the replacement of the exisiting body of water with a different one from below. The present data may appear insufficient to establish this conclusively but the indications are fairly. clear.

Upwelling of the waters along the East Coast of India has been reported by La Fond $(1954,1955)$ and along the East African and Arabian Coasts by Sewell (1955). From an examination of vertical temperature sections and seasonal surface temperature and salinity cycles, La Fond has shown that upwelling takes place along the Visakhapatnam Coast between March and April when the prevailing winds are from the South-West. It could be seen that in those months the trend of surface water is seaward, almost similar to what has been indicated by us along this coast between December and February.

The intensity of the northerly winds begins to decrease from the beginning of March. The summer heating of the surface waters takes place and the surface temperature begins to increase. The coastal circulation is reversed in direction-instead of the waters flowing away from the coast, the flow is towards the coast. The force of the onshore current increases as South-West monsoon season approachs. A general rise in surface salinity of these waters is seen in the months following March. This rise in salinity is partly due to evaporation and partly due to admixture with the high salinity water, from the Persian Gulf brought in by the onshore currents during this period. The prevalence of high salinity may be explained as being due to the operation of these factors.

It could thus be seen that the hydrological conditions of these waters are very much influenced by the prevailing seasons, which can be described 
as Pre-South-West monsoon, South-West monsoon, Transition, and NorthEast monsoon.

We are thankful to Dr. N. K. Panikkar, Chief Research Officer, Central Marine Fisheries Research Station, Mandapam, for his keen interest and encouragement in the course of these investigations, and in the preparation of this paper for publicaiton.

\section{SUMMARY}

The distribution of surface temperature and salinity in the waters of the Arabian Sea along the Bombay and Saurashtra coasts is presented and discussed.

The two factors show seasonal trends associated with the prevalence of the two monsoons, South-West and North-East.

In general, waters North of $20^{\circ} \mathrm{N}$. latitude have a higher salinity and lower temperature than waters South of it.

The variations in salinity and temperature indicate the possibility of seasonal upwelling in the coastal waters between $20^{\circ}$ and $21^{\circ} \mathrm{N}$. latitude and to a less extent upto $22^{\circ} \mathrm{N}$. latitude during the period December to February.

It is suggested that these mixing phenomena may be of great importance in determining the fertility of these waters.

\section{REFERENCES}

Bal, D. V., Pradhan, L. B. and Gupte, K. G.

British Admiralty

La Fond, E. C.
"A preliminary accourit of some physical and chemical factors in the waters of the Bombay Harbour, during 1944-45," Proc. Ind. Acad. Sci., 1946, 24 B (2), 60-74.

West Coast of India Pilot," 9th Edn. Hydrographic Department, Admiralty London, 1950.

"On upwelling and sinking off the East Coast of India," Andhra Univ. Mem. Oceanog., 1954, 1, 117-21.

"On upwelling and fisheries," Curr. Sci., 1955, 24 (8), 258-59.

. " A study of the Sea Coast of Southern Arabia," Proc. Linn. Soc. Lond. (Session 1952-53), Part II, 1955.

Sewell, R. B. S.

Sverdrup, H. U., Johnson, M. W. T and Fleming, R. H.

Veen, P. Ch.

Prentice-Hall, 1942. 1-1087.

. "Preliminary charts of the mean salinity of the Indonesian Archipelago and adjacent seas," Bulletin No. 17, Organization for Scientific Research in Indonesia, Djakarta, 1953. 